\title{
Quantitative Literacy on the Web of Science, 1: The Bibliography and its Role in the History of this Journal
}

H L. Vacher

Department of Geology, University of South Florida, vacher@usf.edu

Todd Chavez

University of South Florida Libraries, tchavez@usf.edu

Follow this and additional works at: https://digitalcommons.usf.edu/numeracy

Part of the Mathematics Commons, and the Science and Mathematics Education Commons

\section{Recommended Citation}

Vacher, H L., and Todd Chavez. "Quantitative Literacy on the Web of Science, 1: The Bibliography and its Role in the History of this Journal." Numeracy 1, Iss. 2 (2008): Article 2. DOI: http://dx.doi.org/10.5038/ 1936-4660.1.2.2 


\title{
Quantitative Literacy on the Web of Science, 1: The Bibliography and its Role in the History of this Journal
}

\begin{abstract}
Prior to deciding to propose in 2006 that the National Numeracy Network (NNN) publish a new journal for quantitative literacy with their support, the University of South Florida Libraries investigated the publication environment of the field on the Web of Science ${ }^{\circledR}$. Reproducing part of that study in this paper, we present findings from topic searches (March 2008) for "numeracy," "quantitative literacy," and "statistical literacy." These updated results include a combined bibliography of 338 peer-reviewed articles amongst 210 different journals, by 748 authors from 321 institutions in 25 countries, in a total of 87 subjects (34\% of the subject classes in Web of Science). Publication dates indicate exponential growth since 1974, with a doubling time of 4.8 years. Citation patterns argue that the field would benefit from the development of a hub journal. With the exception of citation-connected papers in medicine, health science and public health ( $21 \%$ of the collection), the papers of the bibliography are either completely isolated $(54 \%)$ on a citation graph or in relatively small, weakly connected clusters. Very few are cited in prominent edited volumes associated with the NNN. In keeping with the concept that this journal will become a hub journal for the field as envisioned by the proposal from the USF Libraries, this paper presents the bibliography as well as a link and guide to an online version of the Histcite ${ }^{\circledR}$ citation graph where readers can browse the abstracts.
\end{abstract}

\section{Keywords}

bibliography

\section{Creative Commons License}

cc) (1) (8)

This work is licensed under a Creative Commons Attribution-Noncommercial 4.0 License 


\section{Introduction}

The Board of Directors of the National Numeracy Network decided at its second annual meeting (August 2006) to develop a new online journal (Madison and Steen 2008a) - a decision which came to fruition when Numeracy was launched in January of this year. The board's decision was in response to a proposal submitted by the University of South Florida Libraries, who volunteered to support the project as part of its alignment with the Association of Research Libraries' 2005-2009 strategic plan. ${ }^{1}$

Before the USF Libraries could make such a proposal and commit to such support, its Director of Collection Analysis \& Technical Services (TC) needed to prepare an internal business plan, of course. That business plan included an investigation of the publication environment of quantitative literacy (QL). A compelling part of that investigation consisted of a quick look at what "quantitative literacy" and "numeracy" turn up in a topic search on Web of Science (WoS). The search revealed a bibliography consisting of hundreds of papers unfamiliar to the first author. That finding was disconcerting because he thought he was reasonably well read on the subject.

The disconnect between that bibliography and the familiar references outside the impact journals indexed by WoS - not to mention the largely disconnected, fragmented nature of the network of papers within that bibliography - argue for the potential benefits to QL education that would derive from an across-thecurriculum QL journal that could serve as a hub for scholarly activities in QL. With that concept in mind, this paper aims to acquaint readers of Numeracy with the vast network of papers published in the so-called impact journals. We present here the bibliography from a topic search of "numeracy", "quantitative literacy", and "statistical literacy" and a view of its citation graph. We also provide separately an online interactive version that provides access to the abstracts of many of the papers plotted on the graph. And we recount some observations that helped make the case for the USF Libraries to support the initiation of Numeracy with the objective of developing an open-access hub journal for QL.

\footnotetext{
1 "ARL will be a leader in the development of effective, extensible, sustainable, and economically viable models of scholarly communication that provide barrier-free access to quality information in support of teaching, learning, research, and service to the community" (Association of Research Libraries, 2005).
} 


\section{Web of Science and HistCite}

Thomson Reuter's ISI $^{2}$ Web of Science ${ }^{\circledR}(W o S)$ is an online citation index available at many academic libraries. As of June 20, 2008, it provides access to some 10,200 journals through the Science Citation Index (SCI, 1900-present, $67.6 \%$ of the journals), the Social Citation Index (SSCI, 1956-present, 19.9\%), and the Arts \& Humanities Citation Index (A\&HCI, 1975-present, >12.5\%) (Thomson Scientific, n.d.). The database can be searched by topic, title, author, journal, date, and Boolean combinations of these. WoS provides a variety of tools to analyze the results of the search and to explore the network of publications connected by the references and citations within the indexed journals. It is common practice now for researchers to try to keep up with their field by searching and analyzing this database.

Researchers familiar with $W o S$ are well aware that this library resource has limitations. It is common knowledge that WoS does not routinely index books, edited volumes, symposium proceedings, government publications, gray literature, and Web sites, for example. ${ }^{3}$ Also, it does not come close to indexing all journals. ${ }^{4}$ Although 10,200 may seem like a huge number of journals, the number is small compared to the total volume of periodicals $\left(300,000^{5}\right.$ in Ulrich's Periodical Directory $\left.{ }^{6}\right)$. More specifically, many peer-review journals where one might seek papers on numeracy are not included (e.g., The College Mathematics Journal [Mathematics Association of America], Teaching Mathematics [National

2 Developed following Eugene Garfield's 1955 conceptualization of citation indexing and searching (see http://isiwebofknowledge.com/currentuser_wokhome/cu_wokhistory/ for additional information and a history).

${ }^{3}$ However, according to the current product specifications, the resource covers 5,000 books, 192,000 conference proceedings, and 5,000 Websites, as well as 23-million patents and 2- million chemical structures (Thompson Scientific, n.d.).

${ }^{4}$ The rationale for selection is a "bang for your buck" argument. Articles are not uniformly distributed amongst journals. Librarians are well aware of the Bradford distribution (a Pareto-like, inverse power law) that says the overwhelming preponderance of articles is in disproportionately few journals, and they use the concept in selecting subscriptions with a limited budget. Garfield (1972) found a similar distribution for citations: back when SCI indexed 2200 journals (1969), "only 25 journals (a little more than $1 \%$ of SCI coverage) are cited in $24 \%$ of all references; only 152 journals are cited in 50\% of all references; only 767 journals are cited in $75 \%$ of all references" and so on. He concluded: "Going beyond Bradford's studies, I can say that a combination of the literature of individual disciplines and specialties produces a multidisciplinary core for all of science comprising no more than 1000 journals."

${ }^{5}$ This number refers to all periodicals, including newspapers and trade magazines. We do not have a figure for the total number of peer-review journals. Garfield (1972) noted the "contention" ("highly debatable" he said) of 50,000-100,000 for the number of scientific and technical journals. That, of course, was many years ago.

${ }^{6} \mathrm{http}: / / \mathrm{ulrichsweb.com/ulrichsweb/}$ 
Council of Teachers of Mathematics], Journal of College Science Teaching [National Science Teachers Association], The Physics Teacher [American Association of Physics Teachers], Journal of Geoscience Education [National Association of Geoscience Education], Journal of Education for Business, Journal of Statistics Education, Chance).

On the other hand, the subset of journals indexed by WoS is crucially important to the dissemination of research. They are also vitally important to academic researchers interested in professional advancement. These journals, which are all peer-review journals and are selected on the basis of proactive application, are, by sort of self-fulfilling definition, the infamous impact journals defined by the "impact factor" measure (Garfield 1972, 2005; Monastersky 2005; Lawrence 2007) and a new measure by which research faculty are increasingly evaluated, the H-index (Hirsch 2005). Indeed when we team-taught a projectoriented seminar course Geologic Information to USF geology graduate students during spring 2008, two key messages to students preparing for careers with a healthy portion of geological research were: "It doesn't count as research unless it's published," and "It's not published unless it's published in an impact journal."

One reason for the enormous impact of WoS on scientific research is the ease with which researchers can use it to find the core peer-reviewed literature of their field, and then browse the key papers identified by the network of citations. This great facility has been increased substantially with the development of HistCite, ${ }^{7}$ a software application that enables users to chart and explore the citation graphs of bibliographies that they create on WoS. The vertices (nodes) in HistCite citation graphs are the papers of the selected bibliography; the edges (links) show the citations; the vertices can be shown as circles with areas proportional to the number of citations; and the vertices are arranged vertically by date. Because of the last feature, the citation graphs are called "historiographs" in the language of HistCite. With a historiograph, users can quickly visualize the development of the literature of interest and easily pick out influential papers and emerging research fronts. Moreover, by hovering the mouse over any given vertex, the researcher gains access to the bibliographic and citation information of the paper as well as its abstract, if the $W o S$ includes one.

\section{The Bibliography and Its Historiograph}

Topic searches in WoS find the papers using the search terms in the title, keywords and abstract (if included) of papers in the database. For the purpose of

\footnotetext{
7 "HistCite ${ }^{\circledR}$ is a software implementation of algorithmic historiography, and has been developed by Dr. Eugene Garfield, founder of the Institute of Scientific Information and the inventor of the Science Citation Index®" (HistCite, n.d.).
} 
this paper, we conducted three topic searches: for "numeracy" (8 March 2008), "quantitative literacy" (29 February), and "statistical literacy" (29 February). In all, we found 338 unique articles in the three searches.

The 338 articles are listed in the bibliography of the appendix together with an abbreviation (N, QL, SL) indicating the search term that found each of them. Thus the bibliography of the appendix is the union of three single-search term bibliographies: the N-Bibliography (290 articles), QL-Bibliography (29) and SL Bibliography (25).

The historiograph of the combined bibliography is shown in Figure 1. Obviously, it contains too much information for a page in a journal. Fortunately, HistCite includes an HTML-publishing feature that enables one to post an interactive presentation of the results of a WoS bibliographic search. We encourage interested readers to go to our "HistCite - Select Bibliography Concerning Numeracy, Quantitative Literacy and Statistical Literacy, 19262008"8 (hereinafter, "HistCite Bibliography"). This online HistCite Bibliography opens with a bibliographic listing of the 338 references, which can be sorted by date, alphabetically by author, and alphabetically by journal. Click on Historiographs. The first option "Citation patterns within the select bibliography" is a large-scale version of Figure 1 . The other three options produce historiographs for the N-, QL- and SL-Bibliographies. One needs to scroll both vertically and horizontally to browse the graph. Allow time to peruse the abstracts.

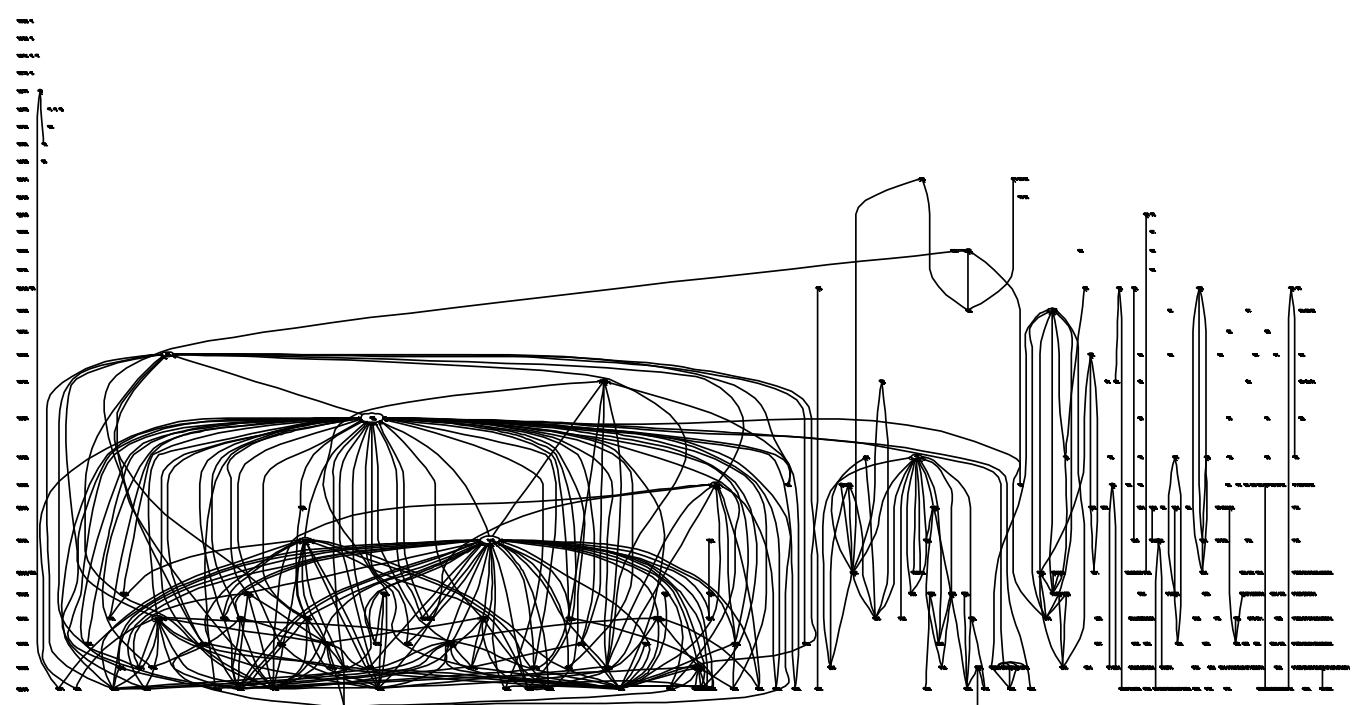

Figure 1. Historiograph for the Bibliography in the Appendix: 338 vertices, 312 edges; one large cluster; several small clusters; few cross-connections; many isolated vertices.

\footnotetext{
${ }^{8}$ http://www.lib.usf.edu/Numeracy/V-C__2008-07/
} 
One can access the abstracts either on the historiographs or on the "List of All Records" page. At either place, clicking on the record number of the paper retrieves the abstract as a popup in a separate window. For example, when the all-records page is sorted by author, Adamsprice (1993) is the first record in the sorted list. It is "record number 43", meaning it is the $43^{\text {rd }}$ record chronologically. (Abstracts start at record 28, in 1992.)

Information about each paper's references and citations is available on the all-records page, the historiographs, and the abstract popups. The terminology is as follows. "Local" refers to the collection, in this case the 338 papers in the bibliography; thus LCS (Local Citation Score) is the total number of later papers in the collection that cite the paper in question, and LCR (Local Cited References) is the number of earlier papers in the collection that the paper in question cites. "Global" refers to all the other papers in the WoS database and is used in GCS, the Global Citation Score. CR, meaning Cited References, is the number of references both inside and outside of WoS. The papers can be sorted on the allrecords page by any of these variables. Thus one can learn easily that Schwartz et al. (1997) is cited the most times (LCS=50) by other papers in this collection; that Williams et al. (1995) is cited the most times $(\mathrm{GCS}=341)$ by papers in impact journals; that Ancker and Kaufman (2007) cites the most number of papers ( $\mathrm{LCR}=18)$ in this collection; and Thomas (1987) cites the most papers (CR=204).

\section{Some Observations}

The bibliographic listing and its citation graph contain a wealth of information. For the purpose of this paper, we focus here on some observations that the USF Libraries found compelling when they decided to propose that NNN publish a scholarly journal in numeracy.

- The number of new papers using the terms "numeracy," "quantitative literacy," and "statistical literacy" is growing at an increasing rate. In fact, the growth of the bibliography has been exponential. Ignoring the two early references (Henschen 1926; Kaiser 1936), and starting with $t_{0}=1974$ when the impact-journal papers began appearing regularly, the size of the bibliography can be described by $2.535 \exp \left[0.1444\left(t-t_{0}\right)\right]\left(r^{2}=0.99\right)$, where $t$ is the publication year. The implied doubling time is 4.8 years. ${ }^{9}$

\footnotetext{
${ }^{9}$ For comparison, the well-known doubling time for scientific literature (de Solla Price 1965) is about 15 years (It was derived from Garfield's SCI data for 1961; for interesting discussion see Griffith 1988). The value for geological literature indexed by the American Geological Institute's GeoRef data base is about the same (Fratesi and Vacher 2008). For the literature of climate change, it is 11 years (Stanhill 2001).
} 
- The reach of the three terms is broad; they represent an emerging multidisciplinary field. WoS uses a detailed classification scheme of 256 subjects to tag the articles. The 338 articles of the bibliography are classified into 87 (34\%) of those classes (with numerous double-counting, such as "education" in combination with some other subject). That means about a third of the subjects covered by the WoS database is touched by the papers on the subject of this journal.

- The authors using the terms are large in number and widely distributed; the interest in numeracy is global. The 338 papers have a total of 748 authors, associated with 321 institutions in 25 countries (less than half from the US).

- Bibliographically, the literature is widely scattered and disjointly distributed. The field is wanting of a hub journal. The fragmented nature of the literature is seen in a variety of ways:

- The 338 papers are distributed amongst 210 journals. Only three journals have 10 or more of the papers: British Educational Research Journal (12), American Statistician (11), Medical Decision Making (11). Nearly three-quarters of the journals (155/210) have but a single article.

- The journals of the three bibliographies (N, QL, and SL) do not overlap much; broadly speaking, users of the three terms use different journals. For example 70\% (12/17) of the journals of the QL-Bibliography contain most $(52 \%$; 15/29) of the papers of that bibliography, and they have none of the papers included in either of the other bibliographies. Similarly, 54\% (7/13) of the journals of the SL-Bibliography have 29\% (7/25) of the statistical literacy papers and none of the papers in either of the other bibliographies.

- The overall view of the historiograph (Fig. 1) is that there is one large cluster; a few weakly connected, small clusters; and many disconnected individuals. Regarding the latter, 251 (74\%) of the papers are not cited by any other paper in the bibliography, 220 $(65 \%)$ do not reference any other paper in the bibliography, and 182 (54\%) neither cite nor are cited by another paper in the bibliography. The eye-catching tangle is a network of interconnected references with waves of evident benchmarks (Williams et al., 1995; Adelsward and Sachs 1996; Baker et al. 1999; Wolsohin et al. 2001; Lipkus et al. 2001) (Fig. 2). This cluster in the field of medicine, health sciences and public health contains 70 references (21\% of the bibliography; $45 \%$ of the references that have any connection with others in the 
bibliography). Other clusters evident in the historiograph include cascades from Brown et al. (1998) on the National Numeracy Strategy (UK), from Wallman (1993) on statistical literacy, from Riverabitiz (1992) on employment, and from Bialystok (1992) on cognitive development. These clusters are nearly to completely disjoint from each other and the large medicine-health cluster.

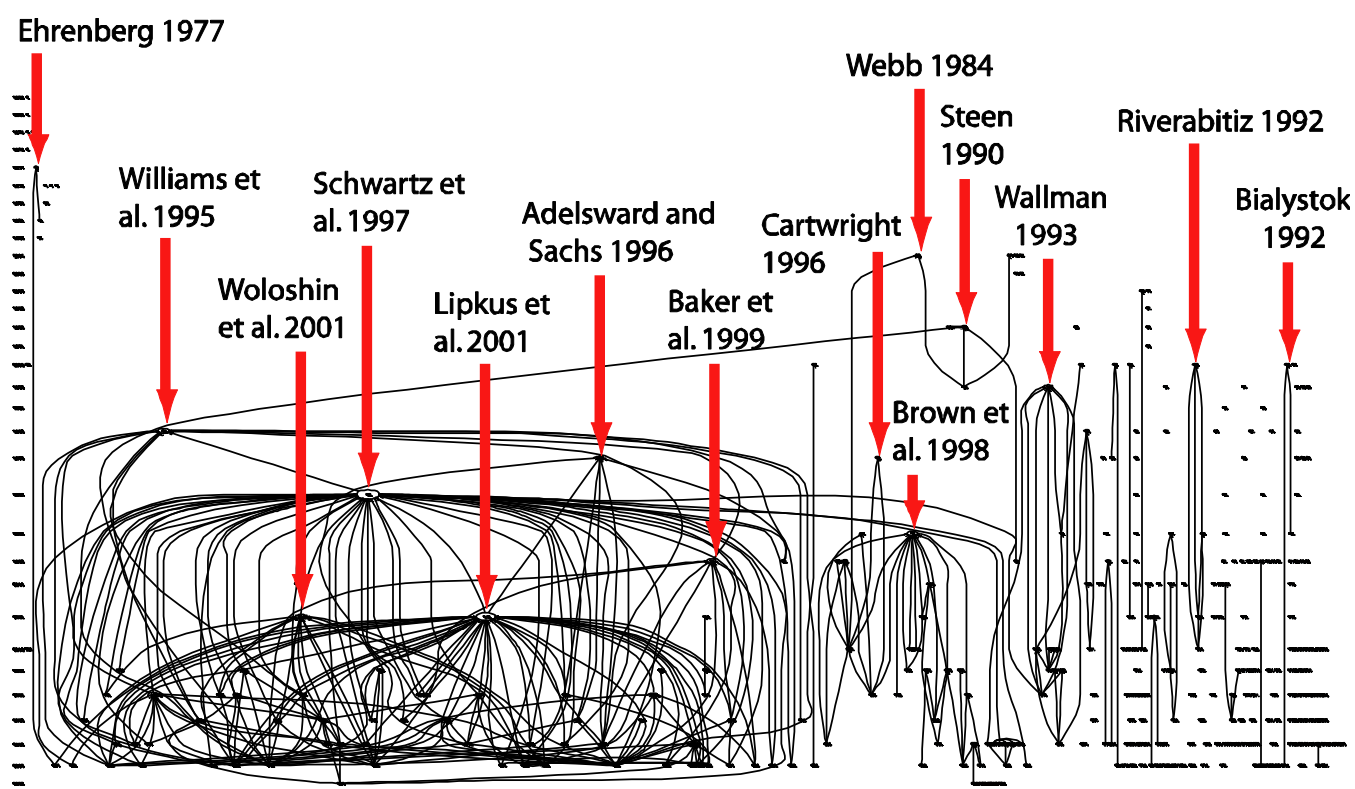

Figure 2. Benchmark Papers in the Bibliography

- The literature of the HistCite bibliography (Figures 1 and 2) is largely disjoint from the "familiar literature of QL outside the impact journals," as we asserted in the Introduction. The disjunction can be substantiated in various ways - most easily by a quick look at the community of authors. We take as hallmarks of "the familiar literature" the prominent edited volumes by Steen (2001), Madison and Steen (2003), Gillman (2006) and Madison and Steen (2008b). All told, there are 90 papers in these collections and 100 different authors and members of advisory groups (design team for Steen 2001; steering committee for Madison and Steen 2008b). This community overlaps hardly at all with the 748 authors in the HistCite bibliography. Only four individuals are in both groups: Joel Best, Richard Scheaffer, Lynn Steen and Jessica Utts, accounting for a total of seven of the 338 papers in the HistCite bibliography. More laborious would be a compilation of the cited references in those 90 papers. We leave it 
to interested readers to browse the classic edited volumes; we are convinced from our scan that those papers tend to cite books, edited volumes, symposium proceedings and official documents and very few papers in journals indexed by WoS. In fact, the only papers in the HistCite bibliography that we recognized in the references of the familiar QL edited volumes are Steen (1990) (by Steen 2003); Steen (1999) (by Design Team 2001 and Steen 2003) and Nolan and Speed (1999) (by Lutsky 2008). In other words, the HistCite bibliography provides a window to a numeracy literature that differs dramatically from the familiar QL literature of the monographs and edited volumes.

\section{Concluding Remarks}

This paper is a case example of how topic searches in Web of Science contributed to a university library's decision: Should the USF Libraries support the initiation of a new journal in QL? From the Libraries' perspective, the motivating reality is that subscriptions to academic journals continue to increase in cost, even to the extent that researchers and readers are becoming unable to afford them and libraries are becoming unable to provide them. Thus a priority drive for USF Libraries is to contribute to global dissemination of important information by making it openly accessible to users regardless of their economic level or affiliation with an academic or commercial entity. The questions that needed to be answered, therefore, had to do with the field of QL - its importance, viability and level of interest - and whether a new journal would make a difference. For "importance," the question was, is it multidisciplinary? For viability, the question was, is it an emerging, growing field? For level of interest, the question was, is there a global constituency with lots of potential authors? The evidence from $W o S$ supported an affirmative answer to all of these questions. Regarding making a difference, it is more than evident in the HistCite graphs that this emerging field wants a hub journal.

\section{Acknowledgments}

We thank the former and current deans of the USF Libraries who have made the USF support of the Numeracy project possible. Dean Derrie Perez, who was a driving force in adopting open-access journal publishing as a part of the Libraries' strategic plan, had the vision to encourage - and fund - the initiation of the journal. Dean William Garrison is similarly committed to the project, and to expanding the Libraries' support to additional globally relevant, multidisciplinary areas of research. We also thank the three anonymous reviewers for their helpful feedback. 


\section{References}

Adamsprice, C. E. 1993. Age, education, and literacy skills of adult Mississippians. Gerontologist 33, (6) (DEC): 741-6.

Adelsward, V., and L. Sachs. 1996. The meaning of 6.8: Numeracy and normality in health information talks. Social Science \& Medicine 43, (8) (OCT): 11791187. http://dx.doi.org/10.1016/0277-9536(95)00366-5

Ancker, J. S., and D. Kaufman. 2007. Rethinking health numeracy: A multidisciplinary literature review. Journal of the American Medical Informatics Association 14, (6) (NOV-DEC): 713-21. http://dx.doi.org/ 10.1197/jamia.M2464

Association of Research Libraries. 2005. ARL Strategic Plan, 2005-2009. http://www.arl.org/arl/governance/stratplan.shtml (accessed Feb 2, 2007).

Baker, D. W., M. V. Williams, R. M. Parker, J. A. Gazmararian, and J. Nurss. 1999. Development of a brief test to measure functional health literacy. Patient Education and Counseling 38, (1) (SEP): 33-42. http://dx.doi.org/ 10.1016/S0738-3991(98)00116-5

Bialystok, E. 1992. Symbolic representation of letters and numbers. Cognitive Development 7, (3) (JUL-SEP): 301-316. http://dx.doi.org/10.1016/08852014(92)90018-M

Brown, M., M. Askew, D. Baker, H. Denvir, and A. Millett. 1998. Is the National Numeracy Strategy research-based? British Journal of Educational Studies 46, (4) (DEC): 362-385. http://dx.doi.org/10.1111/1467-8527.00090

Cartwright, M. 1996. Numeracy needs of the beginning registered nurse. Nurse Education Today 16, (2) (APR): 137-143. http://dx.doi.org/10.1016/S02606917(96)80071-2

Design Team (The Quantitative Literacy Design Team) 2001. The case for quantitative literacy. In Steen L.A. (ed.), Mathematics and Democracy: The case for quantitative literacy, ed. L.A. Steen.1-22. Princeton: National Council on Education and the Disciplines. http://www.maa.org/q1/001-22.pdf

De Solla Price, D.J. 1965. Networks of scientific papers. Science 149: 510-515. http://dx.doi.org/10.1126/science.149.3683.510

Ehrenberg, A.S. C. 1977. Rudiments of numeracy. Journal of the Royal Statistical Society Series A-Statistics in Society 140: 277+.

Fratesi S.E. and H.L. Vacher 2008. Scientific journals as fossil traces of sweeping change in the structure and practice of modern geology. Journal of Research Practice 4(1), article M1 (online journal) http://jrp.icaap.org/ index.php/jrp/article/view/128/106 (accessed June 26. 2008)

Garfield, E. 1972. Citation analysis as a tool in journal evaluation. Science 178: 471-479. http://dx.doi.org/10.1126/science.178.4060.471 
Garfield, E., 2005. The agony and the ecstasy: The history and meaning of the journal impact factor. International Congress on Peer Review and Biomedical Publication, Chicago, 16 September 2005. http://garfield. library.upenn.edu/papers/jifchicago2005.pdf (accessed June 20, 2008).

Gillman, R. (ed.). 2006. Current practices in quantitative literacy. MAA Notes \#70. Washington DC. Mathematical Association of America.

Griffith, B.C. 1988. Derek Price's puzzles: Numerical metaphors for the operation of science. Science, Technology, and Human Values 13(3\&4): 351-360. Reprinted at: http://www.garfield.library.upenn.edu/essays/ v12p193y1989.pdf (accessed June 20, 2008)

Henschen, S. E. 1926. Function of the right brain hemisphere in the relation to the left, in reference to speech, music and numeracy. Zeitschrift Fur Die Gesamte Neurologie Und Psychiatrie 100: 1-16. http://dx.doi.org/10.1007/ BF02970901

Hirsch, J. E., 2005. An Index to Quantify an Individual's Scientific Research Output. Proceedings of the National Academy of Sciences, v. 102, issue 46, 16569-16572. http://dx.doi.org/10.1073/pnas.0507655102

HistCite n.d. HistCite: Bibliometric analysis and visualization software. http://www.histcite.com/about.htm (accessed June 25 2008).

Kaiser, R. 1936. Numeracy and experimental investigation of deflections and tensions of quadratic plates with freer support on the verges, evenly distributed loads and big deflections. Zeitschrift Fur Angewandte Mathematik Und Mechanik 16: 73-98. http://dx.doi.org/10.1002/zamm.19360160203

Lawrence, P.A. 2007. The mismeasurement of science. Current Biology, 17 (15): R583.585. http://dx.doi.org/10.1016/j.cub.2007.06.014

Lipkus, I. M., G. Samsa, and B. K. Rimer. 2001. General performance on a numeracy scale among highly educated samples. Medical Decision Making 21, (1) (JAN-FEB): 37-44. http://dx.doi.org/10.1177/0272989X0102100105

Lutsky, N. 2008. Arguing with numbers: Teaching quantitative reasoning through argument and writing. In Calculation and Context: Quantitative Literacy and Its Implications for Teacher Education, ed. B.L. Madison and L.A.Steen, 59-74. Washington DC: Mathematical Association of America

Madison, B. and L.A. Steen., 2003. Quantitative Literacy: Why Numeracy Matters for Schools and Colleges. Princeton: The National Council on Education and the Disciplines. http://www.maa.org/Q1/qltoc.html

Madison, B. L. and L.A. Steen 2008a. Evolution of Numeracy and the National Numeracy Network. Numeracy 1(1): article 2. http://dx.doi.org/10.5038/ 1936-4660.1.1.2

Madison, B.L. and L.A. Steen (eds.) 2008b. Calculation and Context: Quantitative Literacy and Its Implications for Teacher Education. Washington DC: Mathematical Association of America. 
Nolan, D., and T. P. Speed. 1999. Teaching statistics theory through applications. American Statistician 53, (4) (NOV): 370-375.

Monastersky, R., 2005. The Number that's Devouring Science. The Chronicle of Higher Education, October 14, 2005. http://chronicle.com/free/v52/i08/ 08a01201.htm (accessed March 28, 2008).

Riverabatiz, F. L. 1992. Quantitative literacy and the likelihood of employment among young-adults in the United States. Journal of Human Resources 27, (2) (SPR): 313-328.

Schwartz, L. M., S. Woloshin, W. C. Black, and H. G. Welch. 1997. The role of numeracy in understanding the benefit of screening mammography. Annals of Internal Medicine 127, (11) (DEC 1): 966-72.

Stanhill, G. 2001. The growth of climate change science: A scientometric study. Climate Change 48(2-3): 515-524. http://dx.doi.org/10.1023/A:1010721600 896

Steen, L. A. 1990. Numeracy. Daedalus 119, (2) (SPR): 211-231.

Steen, L. A. 1999. Numeracy - The new literacy for a data-drenched society. Educational Leadership 57, (2) (OCT): 8-13.

Steen, L. (ed.) 2001. Mathematics and Democracy: The Case for Quantitative Literacy. Princeton: National Council on Education and the Disciplines. http://www.maa.org/ql/mathanddemocracy.html

Steen. L.A. 2003. Data, shapes, symbols: Achieving balance in school mathematics. In Quantitative literacy: Why numeracy matters for schools and colleges, ed. B.L. Madison and L.A. Steen, 53-74. Princeton NJ: National Council on Education and the Disciplines http://www.maa.org/Q1/ pgs53 74.pdf

Thomas, K. 1987. Numeracy in early modern England. Transactions of the Royal Historical Society 37: 103-132. http://dx.doi.org/10.2307/3679153

Thompson Scientific. n.d. ISI Web of Knowledge Product Specs. Thompson Scientific. http://isiwebofknowledge.com/currentuser_wokhome/ cu_productspecs/ (accessed March 28, 2008).

Wallman, K. K. 1993. Enhancing statistical literacy - enriching our society. Journal of the American Statistical Association 88, (421) (MAR): 1-8. http://dx.doi.org/10.2307/2290686

Williams, M. V., R. M. Parker, D. W. Baker, N. S. Parikh, K. Pitkin, W. C. Coates, and J. R. Nurss. 1995. Inadequate functional health literacy among patients at 2 public hospitals. Jama-Journal of the American Medical Association 274, (21) (DEC 6): 1677-82.

Webb, N. 1984. Levels of adult numeracy. Journal of the Market Research Society 26, (2): 129-39.

Woloshin, S., L. M. Schwartz, M. Moncur, S. Gabriel, and A. N. A. Tosteson. 2001. Assessing values for health: Numeracy matters. Medical Decision 
Making 21, (5) (SEP-OCT): 382-90. http://dx.doi.org/10.1177/0272989X $\underline{0102100505}$

\section{Appendix: The Bibliography}

The abbreviations, $N, Q L$, and SL indicate the terms used to conduct the search in which the

reference was found: numeracy, quantitative literacy, and statistical literacy, respectively.

$\mathrm{N}$

[Anon]. 1974. Pocket numeracy. Wireless World 80, (1461): 109-.

QL Adamsprice, C. E. 1993. Age, education, and literacy skills of adult Mississippians. Gerontologist 33, (6) (DEC): 741-6.

$\mathrm{N}$

Adelsward, V., and L. Sachs. 1996. The meaning of 6.8:

Numeracy and normality in health information talks. Social Science \& Medicine 43, (8) (OCT): 1179-87.

$\mathrm{N}$

Aggarwal, A., J. L. Speckman, M. K. Paasche-Orlow, K. S. Roloff, and T. A. Battaglia. 2007. The role of numeracy on cancer screening among urban women. American Journal of Health Behavior 31, (SEP-OCT): S57-68.

$\mathrm{N}$

Ahlers-Schmidt, C. R., A. L. Golbeck, A. M. Paschal, R. Zackula, and N. T. Taylor. 2006. Breast cancer counts: Numeracy in breast cancer information on the web. Journal of Cancer Education 21, (2) (SUM): 95-8.

SL Ahlgren, A. 2002. Adults' statistical literacy: Meanings, components, responsibilities - Discussion. International Statistical Review 70, (1) (APR): 41-3.

QL Albert, J. 1997. Teaching Bayes' Rule: A data-oriented approach. American Statistician 51, (3) (AUG): 247-53. 1931. Journal of Interdisciplinary History 30, (1) (SUM): 61+. 
Alderman, H., J. R. Behrman, D. R. Ross, and R. Sabot. 1996. Decomposing the gender gap in cognitive skills in a poor rural economy. Journal of Human Resources 31, (1) (WIN): 229-54.

Alexander, S., and A. Sarrafzadeh. 2004. Interfaces that adapt like humans. Computer Human Interaction: Proceedings 3101: 641-5.

Alloway, T. P. 2007. Working memory, reading, and mathematical skills in children with developmental coordination disorder. Journal of Experimental Child Psychology 96, (1) (JAN): 20-36.

Alloway, T. P., and K. J. Temple. 2007. A comparison of working memory skills and learning in children with developmental coordination disorder and moderate learning difficulties. Applied Cognitive Psychology 21, (4) (MAY): 47387.

Ancker, J. S., and D. Kaufman. 2007. Rethinking health numeracy: A multidisciplinary literature review. Journal of the American Medical Informatics Association 14, (6) (NOV-DEC): 713-21.

Ancker, J. S., Y. Senathirajah, R. Kukafka, and J. B. Starren. 2006. Design features of graphs in health risk communication: A systematic review. Journal of the American Medical Informatics Association 13, (6) (NOV-DEC): 608-18.

Anderson, G. L. 2004. William Foster's legacy: Learning from the past and reconstructing the future. Educational Administration Quarterly 40, (2) (APR): 240-58.

Anghileri, J. 2006. A study of the impact of reform on students' written calculation methods after five years' implementation of the National Numeracy Strategy in England. Oxford Review of Education 32, (3) (JUL): 363-80. 
$\mathrm{N}$

$\mathrm{N}$

$\mathrm{N}$

QL

Ansari, D., and A. Karmiloff-Smith. 2002. Atypical trajectories of number development: A neuroconstructivist perspective.

Trends in Cognitive Sciences 6, (12) (DEC): 511-6.

SL Applegate, K. E., and P. E. Crewson. 2004. Statistical literacy. Radiology 230, (3) (MAR): 613-4.

Apter, A. J., J. Cheng, D. Small, I. M. Bennett, C. Albert, D. G. Fein, M. George, and S. Van Horne. 2006. Asthma numeracy skill and health literacy. Journal of Asthma 43, (9) (NOV): 70510 .

Arkes, H. R., V. A. Shaffer, and M. A. Medow. 2007. Patients derogate physicians who use a computer-assisted diagnostic aid. Medical Decision Making 27, (2) (MAR-APR): 189-202.

Atkinson, M. P., R. F. Czaja, and Z. B. Brewster. 2006.

Integrating sociological research into large introductory courses: Learning content and increasing quantitative literacy. Teaching Sociology 34, (1) (JAN): 54-64.

Aubrey, C. 2004. Implementing the foundation stage in reception classes. British Educational Research Journal 30, (5) (OCT): 633-56.

Aubrey, C., and R. Godfrey. 2003. The development of children's early numeracy through key stage 1. British Educational Research Journal 29, (6) (DEC): 821-40.

Aunio, P., J. Hautamaki, P. Heiskari, and J. E. H. Van Luit. 2006. The early numeracy test in Finnish: Children's norms. Scandinavian Journal of Psychology 47, (5) (OCT): 369-78.

$\mathrm{N}$

Baker, D. W. 2006. The meaning and the measure of health literacy. Journal of General Internal Medicine 21, (8) (AUG): 878-83.

Baker, D. W., M. V. Williams, R. M. Parker, J. A. Gazmararian, and J. Nurss. 1999. Development of a brief test to measure functional health literacy. Patient Education and Counseling 38, (1) (SEP): 33-42. 
Banerjee, A. V., S. Cole, E. Duflo, and L. Linden. 2007. Remedying education: Evidence from two randomized experiments in India. Quarterly Journal of Economics 122, (3) (AUG): 1235-64.

Banks, J., and Z. Oldfield. 2007. Understanding pensions: Cognitive function, numerical ability and retirement saving. Fiscal Studies 28, (2) (JUN): 143-70.

Barbarin, O., D. Bryant, T. McCandies, M. Burchinal, D. Early, R. Clifford, R. Pianta, and C. Howes. 2006. Children enrolled in public pre-K: The relation of family life, neighborhood quality, and socioeconomic resources to early competence. American Journal of Orthopsychiatry 76, (2) (APR): 265-76.

Barnato, A. E., H. A. Llewellyn-Thomas, E. M. Peters, L. Siminoff, E. D. Collins, and M. I. Barry. 2007. Comunication and decision making in cancer care: Setting research priorities for decision support. Medical Decision Making 27, (5) (SEPOCT): 626-34.

Barth, H., K. La Mont, J. Lipton, and E. S. Spelke. 2005. Abstract number and arithmetic in preschool children. Proceedings of the National Academy of Sciences of the United States of America 102, (39) (SEP 27): 14116-21.

SL Batanero, C. 2002. Discussion: The role of models in understanding and improving statistical literacy. International Statistical Review 70, (1) (APR): 37-40.

SL Bendell, A., J. Disney, and C. McCollin. 1999. The future role of statistics in quality engineering and management. Journal of the Royal Statistical Society Series D-The Statistician 48: 299313.

QL Bennett, T. B., and S. W. Nicholson. 2007. Research libraries connecting users to numeric and spatial resources. Social Science Computer Review 25, (3) (FAL): 302-18. 
Berry, D. C., and M. Hochhauser. 2006. Verbal labels can triple perceived risk in clinical trials. Drug Information Journal 40, (3): 249-58.

SL Bessant, K. C. 1992. Instructional-design and the development of statistical literacy. Teaching Sociology 20, (2) (APR): 143-9.

SL Best, J. 2005. Lies, calculations and constructions: Beyond how to lie with statistics. Statistical Science 20, (3) (AUG): 210-4.

Bialystok, E. 1992. Symbolic representation of letters and numbers. Cognitive Development 7, (3) (JUL-SEP): 301-16.

Bogue, A. G. 1990. The quest for numeracy - data and methods in American political-history. Journal of Interdisciplinary History 21, (1) (SUM): 89-116.

QL Boland, P. J., and J. Nicholson. 1996. The statistics and probability curriculum at the secondary school level in the USA, Ireland and the UK. Statistician 45, (4): 437-46.

Bornholt, L. J., and R. Wilson. 2007. A general mediated model of aspects of self knowledge (M-ASK): Children's participation in learning activities across social contexts. Applied Psychologyan International Review-Psychologie Appliquee-Revue Internationale 56, (2) (APR): 302-18.

Bottino, R. M., and E. Robotti. 2007. Transforming classroom teaching and learning through technology: Analysis of a case study. Educational Technology \& Society 10, (4): 174-86.

$\mathrm{N}$

Bourke, S. 1979. Community expectations of numeracy in schools. Australian Journal of Education 23, (2): 142-52.

$\mathrm{N}$

Bovill, M., and I. Shaw. 1992. BBC numeracy initiative. Journal of Educational Television 18, (1): 57-9. 
Bowes, J. M., S. Wise, L. Harrison, A. Sanson, J. Ungerer, J. Watson, and T. Simpson. 2004. Child care choices: A longitudinal study of children, families and child care in partnership with policy makers. Australian Educational Researcher 31, (3) (DEC): 69-86.

Brink, C. 1999. Effective numeracy. Transactions of the Royal Society of South Africa 54, : 247-56.

Brito, G. N. O., and M. de Onis. 2006. Growth status and academic performance in Brazilian school age children - growth retardation impairs mathematical but not reading and spelling abilities. Arquivos De Neuro-Psiquiatria 64, (4) (DEC): 921-5.

Brosnan, M. J. 2008. Digit ratio as an indicator of numeracy relative to literacy in 7-year-old British schoolchildren. British Journal of Psychology 99, (FEB): 75-85.

Brown, M., A. Millett, T. Biddy, and D. C. Johnson. 2000. Turning our attention from the what to the how: The National Numeracy Strategy. British Educational Research Journal 26, (4) (SEP): 457-71.

Brown, M., M. Askew, A. Millett, and V. Rhodes. 2003. The key role of educational research in the development and evaluation of the National Numeracy Strategy. British Educational Research Journal 29, (5) (OCT): 655-72.

Brown, M., M. Askew, D. Baker, H. Denvir, and A. Millett. 1998. Is the National Numeracy Strategy research-based? British Journal of Educational Studies 46, (4) (DEC): 362-85.

Brown, R. H. 1993. Modern science - institutionalization of knowledge and rationalization of power. Sociological Quarterly 34, (1) (SPR): 153-68.

Bryan, K., J. Freer, and C. Furlong. 2007. Language and communication difficulties in juvenile offenders. International Journal of Language \& Communication Disorders 42, (5): 50520 . 
$\mathrm{N}$

$\mathrm{N}$

$\mathrm{N}$

$\mathrm{N}$

$\mathrm{N}$

$\mathrm{N}$

$\mathrm{N}$

$\mathrm{N}$
Burkell, J. 2004. What are the chances? Evaluating risk and benefit information in consumer health materials. Journal of the Medical Library Association 92, (2) (APR): 200-8.

Caron, J., E. Latimer, and M. Tousinant. 2007. Predictors of psychological distress in low-income populations of Montreal. Canadian Journal of Public Health-Revue Canadienne De Sante Publique 98, (JUL-AUG): S35-44.

Carpo, M. 2003. Drawing with numbers - Geometry and numeracy in early modern architectural design. Journal of the Society of Architectural Historians 62, (4) (DEC): 448-69.

Cartwright, M. 1996. Numeracy needs of the beginning registered nurse. Nurse Education Today 16, (2) (APR): 137-43.

Case, A., and A. Deaton. 1999. School inputs and educational outcomes in South Africa. Quarterly Journal of Economics 114, (3) (AUG): 1047-84.

Castle, S. 2001. "The tongue is venomous": Perception, verbalisation and manipulation of mortality and fertility regimes in rural Mali. Social Science \& Medicine 52, (12) (JUN): 182741.

QL Caulfield, S. L., and C. H. Persell. 2006. Teaching social science reasoning and quantitative literacy: The role of collaborative groups. Teaching Sociology 34, (1) (JAN): 39-53.

Chaiken, S. R. 1994. The inspection time not studied processing speed ability unrelated to psychometric intelligence. Intelligence 19, (3) (NOV-DEC): 295-316.

Chapman, A., and A. Lee. 1990. Rethinking literacy and numeracy. Australian Journal of Education 34, (3) (NOV): 27789.

QL Chapman, J. W., W. E. Tunmer, and R. Allen. 2003. Findings from the international adult literacy survey on the incidence and correlates of learning disabilities in New Zealand: Is something rotten in the state of New Zealand? Dyslexia 9, (2) (MAY): 7598. 
Charette, M. F., and R. Meng. 1998. The determinants of literacy and numeracy, and the effect of literacy and numeracy on labour market outcomes. Canadian Journal of EconomicsRevue Canadienne D Economique 31, (3) (AUG): 495-517.

Chiswick, B. R., Y. L. Lee, and P. W. Miller. 2003. Schooling, literacy, numeracy and labour market success. Economic Record 79, (245) (JUN): 165-81.

Ciancio, D., A. C. Rojas, K. McMahon, and R. Pasnak. 2001. Teaching oddity and insertion to Head Start children - An economical cognitive intervention. Journal of Applied Developmental Psychology 22, (6): 603-21.

Cole, M. 2007. Giyoo Hatano's analysis of psychological tools. Human Development 50, (1): 73-80.

Cole, M. 2005. Cross-cultural and historical perspectives on the developmental consequences of education. Human Development 48, (4): 195-216.

$\mathrm{N}$

Coplan, R. J., A. M. Barber, and D. G. Lagace-Seguin. 1999. The role of child temperament as a predictor of early literacy and numeracy skills in preschoolers. Early Childhood Research Quarterly 14, (4): 537-53.

$\mathrm{N}$

Corbin, B., O. McNamara, and A. Williams. 2003. Numeracy coordinators: 'Brokering' change within and between communities of practice? British Journal of Educational Studies 51, (4) (DEC): 344-68.

$\mathrm{N}$

Coste-Zeitoun, D., F. Pinton, C. Barondiot, B. Ducot, J. Warszawski, and C. Billard. 2005. Specific remedial therapy in a specialist unit: Evaluation of 31 children with severe, specific language or reading disorders over one academic year. Revue Neurologique 161, (3) (MAR): 299-310. 
17.

$\mathrm{N}$

$\mathrm{N}$

$\mathrm{N}$

$\mathrm{N}$

$\mathrm{N}$

$\mathrm{N}$

$\mathrm{N}$

$\mathrm{N}$

$\mathrm{N}$
Crawford, W. 1995. Numeracy and common-sense - real-world engineering. Library Hi Tech 13, (3): 83-93.

Crombie, W. H., and D. E. Johnson. 1998. Assessment for success in Maori-medium primary schooling? New Zealand Journal of Educational Studies 33, (2): 143-53.

Curtet, C., and Y. Verguet. 1998. Activities preceding the acquisition of numeracy. A $\mathrm{N}$ a E-Approche

Neuropsychologique Des Apprentissages Chez L Enfant 10, (45) (NOV-DEC): 193-4.

Curtin, P. A., and S. R. Maier. 2001. Numbers in the newsroom: A qualitative examination of a quantitative challenge. Journalism \& Mass Communication Quarterly 78, (4) (WIN): 720-38.

QL Daniele, V. A. 1993. Quantitative literacy. American Annals of the Deaf 138, (2) (APR): 76-81.

Davids, S. L., M. M. Schapira, T. L. McAuliffe, and A. B. Nattinger. 2004. Predictors of pessimistic breast cancer risk perceptions in a primary care population. Journal of General Internal Medicine 19, (4) (APR): 310-5.

Davidson, J. K., and D. L. Elliot. 2007. A comparison of elearning in Scotland's colleges and secondary schools: The case of national qualifications in 'core skills'. Journal of Computer Assisted Learning 23, (6) (DEC): 511-22.

Davis, A. 1999. Prescribing teaching methods. Journal of Philosophy of Education 33, (3) (NOV): 387-401.

Davis, T. C., and M. S. Wolf. 2004. Health literacy: Implications for family medicine. Family Medicine 36, (8) (SEP): 595-8.

de Silva, A. P., Y. Leydet, C. Lincheneau, and N. D. McClenaghan. 2006. Chemical approaches to nanometre-scale logic gates. Journal of Physics-Condensed Matter 18, (33) 
(AUG 23): S1847-72.

$\mathrm{N}$

$\mathrm{N}$

$\mathrm{N}$

$\mathrm{N}$

QL

Dennis, M., and M. Barnes. 2002. Math and numeracy in young adults with spina bifida and hydrocephalus. Developmental Neuropsychology 21, (2): 141-55.

Denny, K. 2002. New methods for comparing literacy across populations: Insights from the measurement of poverty. Journal of the Royal Statistical Society Series A-Statistics in Society 165: 481-93.

Devaney, A., and H. Outhwaite. 2005. Learning resource needs of UKNHS support staff. Health Information and Libraries Journal 22, (4) (DEC): 253-61.

Dickerson, A., and F. Green. 2004. The growth and valuation of computing and other generic skills. Oxford Economic PapersNew Series 56, (3) (JUL): 371-406.

Dietz, T. L. 2006. Using data analysis exercises to teach research in sociology of aging online: An examination of student satisfaction. Educational Gerontology 32, (10) (NOVDEC): 807-24.

SL Dippo, C. S. 1998. FedStats promotes statistical literacy. Communications of the ACM 41, (4) (APR): 58-60.

$\mathrm{N}$ Dobrez, D. G., and E. A. Calhoun. 2004. Testing subject comprehension of utility questionnaires. Quality of Life Research 13, (2) (MAR): 369-76.

$\mathrm{N}$

Dollman, J., K. Boshoff, and G. Dodd. 2006. The relationship between curriculum time for physical education and literacy and numeracy standards in South Australian primary schools. European Physical Education Review 12, (2) (JUN): 151-63.

$\mathrm{N}$

Donelle, L., L. Hoffman-Goetz, and J. F. Arocha. 2007.

Assessing health numeracy among community-dwelling older adults. Journal of Health Communication 12, (7) (OCT-NOV): 651-65. 
Donelle, L., L. Hoffman-Goetz, and J. N. Clarke. 2004.

Portrayal of genetic risk for breast cancer in ethnic and nonethnic newspapers. Women \& Health 40, (4): 93-111.

Donlan, C., D. V. M. Bishop, and G. J. Hitch. 1998. Magnitude comparisons by children with specific language impairments: Evidence of unimpaired symbolic processing. International Journal of Language \& Communication Disorders 33, (2) (APR-JUN): 149-60.

Dougherty, C. 2003. Numeracy, literacy and earnings: Evidence from the national longitudinal survey of youth. Economics of Education Review 22, (5) (OCT): 511-21.

Dowker, A. 2005. Early identification and intervention for students with mathematics difficulties. Journal of Learning Disabilities 38, (4) (JUL-AUG): 324-32.

Edwards, A., and J. Warin. 1999. Parental involvement in raising the achievement of primary school pupils: Why bother? Oxford Review of Education 25, (3) (SEP): 325-41.

$\mathrm{N}$

Ehrenberg, A. S. C. 1981. The problem of numeracy. American Statistician 35, (2): 67-71.

$\mathrm{N}$

Ehrenberg, A.S. C. 1977. Rudiments of numeracy. Journal of the Royal Statistical Society Series A-Statistics in Society 140: $277+$.

$\mathrm{N}$

Eisemon, T. O., J. Ratzlaff, and V. L. Patel. 1992. Reading instructions for using commercial medicines. Annals of the American Academy of Political and Social Science 520, (MAR): 76-90.

$\mathrm{N}$

Elkins, J. 2007. Learning disabilities: Bringing fields and nations together. Journal of Learning Disabilities 40, (5) (SEPOCT): 392-9. 
Emigh, R. J. 2002. Numeracy or enumeration? The uses of numbers by states and societies. Social Science History 26, (4) (WIN): 653-98.

Estrada, C. A., M. Martin-Hryniewicz, B. T. Peek, C. Collins, and J. C. Byrd. 2004. Literacy and numeracy skills and anticoagulation control. American Journal of the Medical Sciences 328, (2) (AUG): 88-93.

Evangelou, M., G. Brooks, and S. Smith. 2007. The birth to school study: Evidence on the effectiveness of PEEP, an early intervention for children at risk of educational underachievement. Oxford Review of Education 33, (5) (NOV): 581609.

Fagerlin, A., B. J. Zikmund-Fisher, and P. A. Ubel. 2005. How making a risk estimate can change the feel of that risk: Shifting attitudes toward breast cancer risk in a general public survey. Patient Education and Counseling 57, (3) (JUN): 294-9.

Fagerlin, A., B. J. Zikmund-Fisher, P. A. Ubel, A. Jankovic, H. A. Derry, and D. M. Smith. 2007. Measuring numeracy without a math test: Development of the subjective numeracy scale. Medical Decision Making 27, (5) (SEP-OCT): 672-80.

Fagerlin, A., C. Wang, and P. A. Ubel. 2005. Reducing the influence of anecdotal reasoning on people's health care decisions: Is a picture worth a thousand statistics? Medical Decision Making 25, (4) (JUL-AUG): 398-405.

Fagerlin, A., D. Rovner, S. Stableford, C. Jentoft, J. T. Wei, and M. Holmes-Rovner. 2004. Patient education materials about the treatment of early-stage prostate cancer: A critical review. Annals of Internal Medicine 140, (9) (MAY 4): 721-8.

Fagerlin, A., P. A. Ubel, D. M. Smith, and B. J. ZikmundFisher. 2007. Making numbers matter: Present and future research in risk communication. American Journal of Health Behavior 31, (SEP-OCT): S47-56. 
$\mathrm{N}$

$\mathrm{N}$

$\mathrm{N}$

$\mathrm{N}$

$\mathrm{N}$

$\mathrm{N}$

$\mathrm{N}$

$\mathrm{N}$

$\mathrm{N}$
Faragher, R., and R. I. Brown. 2005. Numeracy for adults with Down syndrome: It's a matter of quality of life. Journal of Intellectual Disability Research 49, (OCT): 761-5.

Feiler, A., P. Greenhough, J. Winter, L. Salway, and M.

Scanlan. 2006. Getting engaged: Possibilities and problems for home-school knowledge exchange. Educational Review 58, (4) (NOV): 451-69.

Ferguson, J. H. 1999. Curative and population medicine: Bridging the great divide. Neuroepidemiology 18, (3) (MAYJUN): 111-9.

Finnie, R. and R. Meng. 2001. Cognitive skills and the youth labour market. Applied Economics Letters 8, (10) (OCT): 675-9. Finnie, R., and R. Meng. 2002. Minorities, cognitive skills and incomes of Canadians. Canadian Public Policy-Analyse De Politiques 28, (2) (JUN): 257-73.

Foran, B., and K. Wardle. 1995. Transitions in land-use and the problems of planning - A case-study from the mountainlands of New Zealand. Journal of Environmental Management 43, (2) (FEB): 97-127.

Fraenkel, L., S. Bogardus, J. Concato, and D. Felson. 2003. Risk communication in rheumatoid arthritis. Journal of Rheumatology 30, (3) (MAR): 443-8.

SL Gal, I. 2002. Adults' statistical literacy: Meanings, components, responsibilities. International Statistical Review 70, (1) (APR): $1-25$.

SL Gal, I. 2002. Response: Developing statistical literacy: Towards implementing change. International Statistical Review 70, (1) (APR): 46-51.

SL Gal, I. 2003. Teaching for statistical literacy and services of statistics agencies. American Statistician 57, (2) (MAY): 80-4. 
Galbraith, P. L., M. C. Carss, R. D. Grice, L. Endean, and M. Warry. 1997. Towards scientific literacy for the third millennium: A view from Australia. International Journal of Science Education 19, (4) (APR-MAY): 447-67.

Garcia-Mila, M., E. Marti, and A. Teberosky. 2004. Emergent notational understanding: Educational challenges from a developmental perspective. Theory into Practice 43, (4) (FAL): 287-94.

Gaugler, J. E., E. Pavlik, J. M. Salsman, and M. A. Andrykowski. 2006. Psychological and behavioral impact of receipt of a "normal" ovarian cancer screening test. Preventive Medicine 42, (6) (JUN): 463-70.

Gaull, M. 1991. Romantic numeracy, the tuneless-numbers and shadows-numberless + Keats 'Ode to Psyche' and 'Ode to a Nightingale'. Wordsworth Circle 22, (2) (SPR): 124-30. Gelman, A., and M. E. Glickman. 2000. Some classparticipation demonstrations for introductory probability and statistics. Journal of Educational and Behavioral Statistics 25, (1) (SPR): 84-100.

SL Gelman, A., D. Nolan, A. Men, S. Warmerdam, and M. Bautista. 1998. Student projects on statistical literacy and the media. American Statistician 52, (2) (MAY): 160-6.

Gladstone, I. M., and V. L. Katz. 2002. A tale of two citations: Counting on numeracy in the digital divide. British Medical Journal 325, (7378) (DEC 21): 1452-3.

Glewwe, P. 1999. Why does mother's schooling raise child health in developing countries? Evidence from Morocco. Journal of Human Resources 34, (1) (WIN): 124-59.

Golbeck, A. L., C. R. Ahlers-Schmidt, A. M. Paschal, and S. E. Dismuke. 2005. A definition and operational framework for health numeracy. American Journal of Preventive Medicine 29, (4) $(\mathrm{NOV}): 375-6$. 
Gong, D. A., J. Y. Lee, R. G. Rozier, B. T. Pahel, J. A. Richman, and W. F. Vann. 2007. Development and testing of the test of functional health literacy in dentistry (TOFHLiD). Journal of Public Health Dentistry 67, (2) (SPR): 105-12.

Gramling, R., D. Anthony, E. Simmons, and D. Bowen. 2006. Self-rated breast cancer risk among women reporting a firstdegree family history of breast cancer on office screening questionnaires in routine medical care: The role of physiciandelivered risk feedback. Genetics in Medicine 8, (10) (OCT): 658-64.

QL Grasso, D., K. M. Callahan, and S. Doucett. 2004. Defining engineering thought. International Journal of Engineering Education 20, (3): 412-5.

Green, J. M., D. C. S. Shearn, and N. Bolton. 1983. A numeracy course for arts undergraduates. Studies in Higher Education 8, (1): 57-65.

Griffin, P. 2007. Mathematics achievement of Vietnamese grade 5 pupils. Asia Pacific Education Review 8, (2) (AUG): 233-49.

Griffin, P., and R. Callingham. 2006. A 20-year study of mathematics achievement. Journal for Research in Mathematics Education 37, (3) (MAY): 167-86.

Gurmankin, A. D., J. Baron, and K. Annstrong. 2004. The effect of numerical statements of risk on trust and comfort with hypothetical physician risk communication. Medical Decision Making 24, (3) (MAY-JUN): 265-71.

Haggstrom, D. A., and M. M. Schapira. 2006. Black-white differences in risk perceptions of breast cancer survival and screening mammography benefit. Journal of General Internal Medicine 21, (4) (APR): 371-7.

Hallam, S., J. Ireson, and J. Davies. 2004. Grouping practices in the primary school: What influences change? British Educational Research Journal 30, (1) (FEB): 117-40. 
Hamilton, M., and Y. Hillier. 2007. Deliberative policy analysis: Adult literacy assessment and the politics of change. Journal of Education Policy 22, (5): 573-94.

Hamm, R. M., D. E. Bard, E. Hsieh, and H. F. Stein. 2007. Contingent or universal approaches to patient deficiencies in health numeracy. Medical Decision Making 27, (5) (SEP-OCT): 635-7.

Hanoch, Y. 2004. Improving doctor-patient understanding of probability in communicating cancer-screening test findings. Journal of Health Communication 9, (4) (JUL-AUG): 327-35.

Hanoch, Y., and T. Pachur. 2004. Nurses as information providers: Facilitating understanding and communication of statistical information. Nurse Education Today 24, (3) (APR): 236-43.

Hartley, D. 2003. New economy, new pedagogy? Oxford Review of Education 29, (1) (MAR): 81-94.

Hay, J., E. Shuk, G. Cruz, and J. Ostroff. 2005. Thinking through cancer risk: Characterizing smokers' process of risk determination. Qualitative Health Research 15, (8) (OCT): 1074-85.

QL Hayden, R. W., and F. Kianifard. 1992. Preparing high-school mathematics teachers to teach statistics. American Statistician 46, (4) (NOV): 290-5.

Hecker, R. 1997. Participatory action research as a strategy for empowering aboriginal health workers. Australian and New Zealand Journal of Public Health 21, (7) (DEC): 784-8.

SL Hellems, M. A., M. J. Gurka, and G. F. Hayden. 2007. Statistical literacy for readers of pediatrics: A moving target. Pediatrics 119, (6) (JUN): 1083-8.

Henschen, S. E. 1926. Function of the right brain hemisphere in the relation to the left, in reference to speech, music and numeracy. Zeitschrift Fur Die Gesamte Neurologie Und Psychiatrie 100: 1-16. 
$\mathrm{N}$

$\mathrm{N}$

$\mathrm{N}$

QL

$\mathrm{N}$

$\mathrm{N}$
Herne, S. 2000. Breadth and balance? The impact of the national literacy and numeracy strategies on art in the primary school (UK). Journal of Art \& Design Education 19, (2): 217-23.

Hetherington, R., M. Dennis, M. Barnes, J. Drake, and F. Gentili. 2006. Functional outcome in young adults with spina bifida and hydrocephalus. Childs Nervous System 22, (2) (FEB): 117-24.

Hibbard, J. H., E. Peters, A. Dixon, and M. Tusler. 2007. Consumer competencies and the use of comparative quality information - It isn't just about literacy. Medical Care Research and Review 64, (4) (AUG): 379-94.

Hilton, S. C., S. D. Grimshaw, and G. T. Anderson. 2001. Statistics in preschool. American Statistician 55, (4) (NOV): 332-6.

Hippisley, J., G. Douglas, and S. Houghton. 2005. A crosscultural comparison of numeracy skills using a written and an interactive arithmetic test. Educational Research 47, (2) (JUN): 205-15.

Hiscock, H., L. Canterford, O. C. Ukoumunne, and M. Wake. 2007. Adverse associations of sleep problems in Australian preschoolers: National population study. Pediatrics 119, (1) (JAN): 86-93.

Holloway, S. D., M. F. Rambaud, B. Fuller, and C. EggersPierola. 1995. What is "appropriate practice" at home and in child care? Low-income mothers' views on preparing their children for school. Early Childhood Research Quarterly 10, (4) (DEC): 451-73.

QL Howery, C. B., and H. Rodriguez. 2006. Integrating data analysis (IDA): Working with sociology departments to address the quantitative literacy gap. Teaching Sociology 34, (1) (JAN): 23-38. 
Hudson, C. 2003. Basic skills provision for offenders on probation supervision: Beyond a rhetoric of evidence-based policy? British Journal of Educational Studies 51, (1) (MAR): 64-81. exchange in context. Educational Review 58, (4) (NOV): 38595.

Hutton, B. M. 1998. Do school qualifications predict competence in nursing calculations? Nurse Education Today 18, (1) (JAN): 25-31.

Isaacs, E. B., A. Lucas, W. K. Chong, S. J. Wood, C. L. Johnson, C. Marshall, F. Vargha-Khadem, and D. G. Gadian. 2000. Hippocampal volume and everyday memory in children of very low birth weight. Pediatric Research 47, (6) (JUN): 71320 .

Isaacs, E. B., C. J. Edmonds, A. Lucas, and D. G. Gadian. 2001. Calculation difficulties in children of very low birthweight - A neural correlate. Brain 124, (SEP): 1701-7.

Jenks, K. M., J. de Moor, E. C. D. M. van Lieshout, K. G. B. Maathuis, I. Keus, and J. W. Gorter. 2007. The effect of cerebral palsy on arithmetic accuracy is mediated by working memory, intelligence, early numeracy, and instruction time. Developmental Neuropsychology 32, (3): 861-79.

Johnson, K. R., and T. V. J. Layng. 1992. Breaking the structuralist barrier - literacy and numeracy with fluency. American Psychologist 47, (11) (NOV): 1475-90.

Jones, S., and H. Tanner. 2002. Teachers' interpretations of effective whole-class interactive teaching in secondary mathematics classrooms. Educational Studies 28, (3) (SEP): 265-74. cultural-practice - an examination of numbers in magazines for children, teenagers, and adults. Journal for Research in 
Mathematics Education 26, (4) (JUL): 346-61.

$\mathrm{N}$

QL
Justus, C. F. 1996. Numeracy and the Germanic upper decades. Journal of Indo-European Studies 24, (1-2) (SPR-SUM): 45-80.

Kain, E. L. 2006. Bridging the gap between cultures of teaching and cultures of research. Teaching Sociology 34, (4) (OCT): 325-40.

Kaiser, R. 1936. Numeracy and experimental investigation of deflections and tensions of quadratic plates with freer support on the verges, evenly distributed loads and big deflections.

Zeitschrift Fur Angewandte Mathematik Und Mechanik 16: 7398.

Kambouri, M., H. Mellar, and K. Logan. 2006. Adult learners and ICT: An intervention study in the UK. Innovative Approaches for Learning and Knowledge Sharing, Proceedings 4227: 213-26.

Kasper, J., S. Kopke, I. Muhlhauser, and C. Heesen. 2006. Evidence-based patient information about treatment of multiple sclerosis- A phase one study on comprehension and emotional responses. Patient Education and Counseling 62, (1) (JUL): 5663.

Kaufman, D. R., V. L. Patel, C. Hilliman, P. C. Morin, J. Pevzner, R. S. Weinstock, R. Goland, S. Shea, and J. Starren. 2003. Usability in the real world: Assessing medical information technologies in patients' homes. Journal of Biomedical Informatics 36, (1-2) (FEB-APR): 45-60.

Kaufmann, L., P. Handl, and B. Thony. 2003. Evaluation of a numeracy intervention program focusing on basic numerical knowledge and conceptual knowledge: A pilot study. Journal of Learning Disabilities 36, (6) (NOV-DEC): 564-73.

Kelly, K. M., K. D. Graves, F. W. K. Harper, J. E. Schmidt, S. L. Dickinson, and M. A. Andrykowski. 2007. Assessing perceptions of cancer risk: Does mode of assessment or numeracy matter? Cancer Detection and Prevention 31, (6): 
465-73.

$\mathrm{N}$

$\mathrm{N}$

$\mathrm{N}$

$\mathrm{N}$

$\mathrm{N}$

$\mathrm{N}$

$\mathrm{N}$

$\mathrm{N}$
Kemp, C., and M. Carter. 2006. The contribution of academic skills to the successful inclusion of children with disabilities. Journal of Developmental and Physical Disabilities 18, (2) (JUN): 123-47.

Kline, T. J. B. 2004. Gender and language differences on the test of workplace essential skills: Using overall mean scores and item-level differential item functioning analyses. Educational and Psychological Measurement 64, (3) (JUN): 549-59.

Kok, L. L., and R. T. Solman. 1995. Velocardiofacial syndrome - learning-difficulties and intervention. Journal of Medical Genetics 32, (8) (AUG): 612-8.

Koponen, T., R. Mononen, P. Rasanen, and T. Ahonen. 2006. Basic numeracy in children with specific language impairment: Heterogeneity and connections to language. Journal of Speech Language and Hearing Research 49, (1) (FEB): 58-73.

Kyriacou, C. 2005. The impact of daily mathematics lessons in England on pupil confidence and competence in early mathematics: A systematic review. British Journal of Educational Studies 53, (2) (JUN): 168-86.

Lake, D. 1999. Helping students to go SOLO: Teaching critical numeracy in the biological sciences. Journal of Biological Education 33, (4) (FAL): 191-8.

Lavery, L., M. Townsend, and K. Wilton. 1998. Computerassisted instruction in teaching literacy skills to adults not in paid employment. New Zealand Journal of Educational Studies 33, (2): 181-92.

Leach, A. J. 1999. Otitis media in Australian aboriginal children: An overview. International Journal of Pediatric Otorhinolaryngology 49, (OCT 5): S173-8. 
$\mathrm{N}$

$\mathrm{N}$

$\mathrm{N}$

$\mathrm{N}$

$\mathrm{N}$

$\mathrm{N}$

$\mathrm{N}$

$\mathrm{N}$
Leach, D. J. 1996. Applying behavioural psychology in education: Contributions and barriers to the implementation of effective instruction. Behaviour Change 13, (1): 3-19.

LeFevre, J. A. 2000. Research on the development of academic skills: Introduction to the special issue on early literacy and early numeracy. Canadian Journal of Experimental PsychologyRevue Canadienne De Psychologie Experimentale 54, (2) (JUN): 57-60.

Leithwood, K., and D. Jantzi. 2006. Transformational school leadership for large-scale reform: Effects on students, teachers, and their classroom practices. School Effectiveness and School Improvement 17, (2) (JUN): 201-27.

Lenert, L., and R. M. Kaplan. 2000. Validity and interpretation of preference-based measures of health-related quality of life. Medical Care 38, (9) (SEP): 138-50.

Lethbridge, D. G., and R. Miles. 1976. Pathways to management numeracy. Omega-International Journal of Management Science 4, (4): 397-405.

Li, H. J., H. X. Barnhart, A. D. Stein, and R. Martorell. 2003. Effects of early childhood supplementation on the educational achievement of women. Pediatrics 112, (5) (NOV 1): 1156-62.

Limage, L. J. 1999. Literacy practices and literacy policies: Where has UNESCO been and where might it be going? International Journal of Educational Development 19, (1) (JAN): 75-89.

Lipkus, I. M., G. Samsa, and B. K. Rimer. 2001. General performance on a numeracy scale among highly educated samples. Medical Decision Making 21, (1) (JAN-FEB): 37-44.

QL Lomax, R. G. 2004. Whither the future of quantitative literacy research? Reading Research Quarterly 39, (1) (JAN-MAR): 107-12. 
Lopez, E. M., R. Gallimore, H. Garnier, and L. Reese. 2007. Preschool antecedents of mathematics achievement of Latinos The influence of family resources, early literacy experiences, and preschool attendance. Hispanic Journal of Behavioral Sciences 29, (4) (NOV): 456-71.

Lu, M., S. A. Safren, P. R. Skolnik, W. H. Rogers, W. Coady, H. Hardy, and I. B. Wilson. 2008. Optimal recall period and response task for self-reported HIV medication adherence. Aids and Behavior 12, (1) (JAN): 86-94.

Lubitz, R. J., M. Komaromy, B. Crawford, M. Beattie, R. Lee, J. Luce, and J. Ziegler. 2007. Development and pilot evaluation of novel genetic educational materials designed for an underserved patient population. Genetic Testing 11, (3) (FAL): 276-90.

Luckin, R., J. Underwood, B. du Boulay, J. Holmberg, and H. Tunley. 2004. Coherence compilation: Applying AIED techniques to the reuse of educational TV resources. Intelligent Tutoring Systems, Proceedings 3220: 98-107.

QL Ma, X. 2005. Early acceleration of students in mathematics: Does it promote growth and stability of growth in achievement across mathematical areas? Contemporary Educational Psychology 30, (4) (OCT): 439-60.

QL Ma, X. 2006. Cognitive and affective changes as determinants for taking advanced mathematics courses in high school. American Journal of Education 113, (1) (NOV): 123-49.

$\mathrm{N}$ Macintyre, H., and J. Ireson. 2002. Within-class ability grouping: Placement of pupils in groups and self-concept. British Educational Research Journal 28, (2) (APR): 249-63.

QL Magajna, L., M. Kavkler, and M. Ortar-Krizaj. 2003. Adults with self-reported learning disabilities in Slovenia: Findings from the International Adult Literacy Survey on the incidence and correlates of learning disabilities in Slovenia. Dyslexia 9, (4) (NOV): 229-51. 
Maier, S. R. 2003. Numeracy in the newsroom: A case study of mathematical competence and confidence. Journalism \& Mass Communication Quarterly 80, (4) (WIN): 921-36.

Marks, G. N. 2008. Are father's or mother's socioeconomic characteristics more important influences on student performance? Recent international evidence. Social Indicators Research 85, (2) (JAN): 293-309.

Massie, R., and H. Dillon. 2006. The impact of sound-field amplification in mainstream cross-cultural classrooms: Part 1 educational outcomes. Australian Journal of Education 50, (1) (APR): 62-77.

QL Matouskova, Z. 2007. Does human capital create competitive advantage of the Czech republic? Politicka Ekonomie 55, (3): 374-98.

Mazor, K. M., J. Baril, E. Dugan, F. Spencer, P. Burgwinkle, and J. H. Gurwitz. 2007. Patient education about anticoagulant medication: Is narrative evidence or statistical evidence more effective? Patient Education and Counseling 69, (1-3) (DEC): 145-57.

McGaghie, W. C. 2002. Assessing readiness for medical education evolution of the medical college admission test. Jama-Journal of the American Medical Association 288, (9) (SEP 4): 1085-90.

McGuinness S., J. Bennett, and G. McCausland. 2008. Service sector SMEs and essential skill provision in the 16-25 year old labour market: Evidence from Northern Ireland. International Journal of Human Resource Management 19, (2): 356-371.

McIntosh, S., and A. Vignoles. 2001. Measuring and assessing the impact of basic skills on labour market outcomes. Oxford Economic Papers-New Series 53, (3) (JUL): 453-81.

McNamara, O., and B. Corbin. 2001. Warranting practices: Teachers embedding the National Numeracy Strategy. British Journal of Educational Studies 49, (3) (SEP): 260-84. 
McNamara, O., L. Roberts, T. N. Basit, and T. Brown. 2002. Rites of passage in initial teacher training: Ritual, performance, ordeal and numeracy skills test. British Educational Research Journal 28, (6) (DEC): 863-78.

Medlicot.P. 1974. School numeracy. New Society 30, (636): 688-9.

Melhuish, E. C., M. B. Phan, K. Sylva, P. Sammons, I. SirajBlatchford, and B. Taggart. 2008. Effects of the home learning environment and preschool center experience upon literacy and numeracy development in early primary school. Journal of Social Issues 64, (1): 95-114.

SL Miller, J. E. 1980. Social-indicators and statistical literacy. Social Studies 71, (5): 226-9. numbers - The challenge of numeracy in health care. Journal of General Internal Medicine 20, (11) (NOV): 1071-2.

Morgan, P. P. 1985. Numeracy - what is it, and who needs it. Canadian Medical Association Journal 133, (3): 178-.

QL Mosenthal, P. B., and I. S. Kirsch. 1993. Profiling students' quantitative literacy abilities - an approach with precision. Journal of Reading 36, (8) (MAY): 668-74.

$\mathrm{N}$

Muijs, D., and D. Reynolds. 2000. School effectiveness and teacher effectiveness in mathematics: Some preliminary findings from the evaluation of the mathematics enhancement programme (primary). School Effectiveness and School Improvement 11, (3): 273-303.

$\mathrm{N}$

Muldoon, K. P., C. Lewis, and B. Francis. 2007. Using cardinality to compare quantities: The role of social-cognitive conflict in early numeracy. Developmental Science 10, (5) (SEP): 694-711. 
$\mathrm{N}$

$\mathrm{N}$

$\mathrm{N}$

$\mathrm{N}$

$\mathrm{N}$

$\mathrm{N}$

$\mathrm{N}$

$\mathrm{N}$

QL
Muldoon, K. P., C. Lewis, and D. Berridge. 2007. Predictors of early numeracy: Is there a place for mistakes when learning about number? British Journal of Developmental Psychology 25, (NOV): 543-58.

Mulhern, G., and J. Wylie. 2004. Changing levels of numeracy and other core mathematical skills among psychology undergraduates between 1992 and 2002. British Journal of Psychology 95, (AUG): 355-70.

Murphy, G. H., H. Harnett, and A. J. Holland. 1995. A survey of intellectual disabilities amongst men on remand in prison. Mental Handicap Research 8, (2): 81-98.

Myhill, D., and M. Brackley. 2004. Making connections: Teachers' use of children's prior knowledge in whole class discourse. British Journal of Educational Studies 52, (3) (SEP): 263-75.

Nath, S. R., and M. R. Chowdhury. 2002. Level and trend of basic education of children in Bangladesh: 1993-1998.

Educational Studies 28, (1) (MAR): 77-92.

Nekhlyudov, L., R. Li, and S. W. Fletcher. 2005. Information and involvement preferences of women in their 40s before their first screening mammogram. Archives of Internal Medicine 165, (12) (JUN 27): 1370-4.

Netz, R. 2002. Counter culture: Towards a history of Greek numeracy. History of Science 40, (129) (SEP): 321-52.

Nicol, M. M., and A. Anderson. 2000. Computer-assisted vs. teacher-directed teaching of numeracy in adults. Journal of Computer Assisted Learning 16, (3) (SEP): 184-92.

Nolan, D., and T. P. Speed. 1999. Teaching statistics theory through applications. American Statistician 53, (4) (NOV): 3705 .

Norwich, B., and A. Lewis. 2001. Mapping a pedagogy for special educational needs. British Educational Research Journal 
27, (3) (JUN): 313-29.

$\mathrm{N}$

$\mathrm{N}$

$\mathrm{N}$

$\mathrm{N}$

$\mathrm{N}$

$\mathrm{N}$

$\mathrm{N}$

$\mathrm{N}$

$\mathrm{N}$
Nusbaum, N. J. 2006. Mathematics preparation for medical school: Do all premedical students need calculus? Teaching and Learning in Medicine 18, (2) (SPR): 165-8.

Obrien, J. 1984. Literacy and numeracy - understanding words and numbers. Journal of the Market Research Society 26, (2): 89-92.

Ogden, L. 2000. Collaborative tasks, collaborative children: An analysis of reciprocity during peer interaction at key stage I. British Educational Research Journal 26, (2) (APR): 211-26.

Parr, J. M. 1997. Computer assisted learning with an integrated learning system: Another front for raising literacy and numeracy amongst secondary students? New Zealand Journal of Educational Studies 32, (1): 37-51.

Parrott, R., K. Silk, K. Dorgan, C. Condit, and T. Harris. 2005. Risk comprehension and judgments of statistical evidentiary appeals - when a picture is not worth a thousand words. Human Communication Research 31, (3) (JUL): 423-52.

Pasnak, R., E. MacCubbin, and M. Ferral-Like. 2007. Using developmental principles to assist preschoolers in developing numeracy and literacy. Perceptual and Motor Skills 105, (1) (AUG): 163-76.

Pasnak, R., M. S. Greene, E. O. Ferguson, and K. Levit. 2006. Applying principles of development to help at-risk preschoolers develop numeracy. Journal of Psychology 140, (2) (MAR): 15573.

Peers, C. 2005. The 'first' educator? Rethinking the 'teacher' through Luce Irigaray's philosophy of sexual difference. Australian Educational Researcher 32, (1) (APR): 83-100.

Peters, E., D. Vastfjall, P. Slovic, C. K. Mertz, K. Mazzocco, and S. Dickert. 2006. Numeracy and decision making. Psychological Science 17, (5) (MAY): 407-13. 
Peters, E., J. Hibbard, P. Slovic, and N. Dieckmann. 2007.

Numeracy skill and the communication, comprehension, and use of risk-benefit information. Health Affairs 26, (3) (MAY-JUN): 741-8.

Peters, E., N. Dieckmann, A. Dixon, J. H. Hibbard, and C. K. Mertz. 2007. Less is more in presenting quality information to consumers. Medical Care Research and Review 64, (2) (APR): 169-90.

Petroski, H. 1985. Numeracy and literacy - the 2 cultures and the computer revolution. Virginia Quarterly Review 61, (2): 302-21. of learning style on progress towards literacy and numeracy. Educational Review 39, (1): 31-40. Biological Education 34, (1) (WIN): 3-4.

Pietersen, C. 2006. Evaluation of a number skills development programme. South African Journal of Education 26, (3) (AUG): 413-26.

Pinton, F., A. Ducot, J. Motte, A. S. Arbues, C. Barondiot, M. A. Barthez, Y. Chaix, et al. 2006. Cognitive functions in children with benign childhood epilepsy with centrotemporal spikes (BECTS). Epileptic Disorders 8, (1) (MAR): 11-23.

Pollitt, E., K. Gorman, P. L. Engle, R. Martorell, and J. Rivera. 1993. Early supplementary feeding and cognition - effects over 2 decades. Monographs of the Society for Research in Child Development 58, (7): R5-R98.

$\mathrm{N}$

Pollitt, E., K. S. Gorman, P. L. Engle, J. A. Rivera, and R. Martorell. 1995. Nutrition in early-life and the fulfillment of intellectual potential. Journal of Nutrition 125, (4) (APR): S1111-8. 
$\mathrm{N}$

$\mathrm{N}$

$\mathrm{N}$

$\mathrm{N}$

$\mathrm{N}$

$\mathrm{N}$

QL Reaven, S. J. 1988. Using science and technology news issues to develop scientific and quantitative literacy. Bulletin of Science Technology \& Society 8, (3): 265-8.

$\mathrm{N}$

Reiff, J. L. 1984. Numeracy, computer literacy, and history - A view from both sides. Historical Methods 17, (4): 265-9.

$\mathrm{N}$

Rennie, J. 2006. Meeting kids at the school gate: The literacy and numeracy practices of a remote indigenous community. Australian Educational Researcher 33, (3) (DEC): 123-42. 
$\mathrm{N}$

$\mathrm{N}$

$\mathrm{N}$

$\mathrm{N}$

$\mathrm{N}$

$\mathrm{N}$
Reyna, V. F., and C. J. Brainerd. 2007. The importance of mathematics in health and human judgment: Numeracy, risk communication, and medical decision making. Learning and Individual Differences 17, (2): 147-59.

QL Riverabatiz, F. L. 1992. Quantitative literacy and the likelihood of employment among young-adults in the United States. Journal of Human Resources 27, (2) (SPR): 313-28.

Robinson, S. P. 1996. With numeracy for all: Urban schools and the reform of mathematics education. Urban Education 30, (4) (JAN): 379-94.

Rothman, R. L., R. Housam, H. Weiss, D. Davis, R. Gregory, T. Gebretsadik, A. Shintani, and T. A. Elasy. 2006. Patient understanding of food labels - The role of literacy and numeracy. American Journal of Preventive Medicine 31, (5) (NOV): 391-8.

Routh, K., J. N. Rao, and J. Denley. 2006. A simple, and potentially low-cost method for measuring the prevalence of childhood obesity. Child Care Health and Development 32, (2) (MAR): 239-45.

SL Rumsey, D. J. 2002. Discussion: Statistical literacy: Implications for teaching, research, and practice. International Statistical Review 70, (1) (APR): 32-6.

SL Scales, C. D., B. Peterson, and P. Dahm. 2006. Interpreting statistics in the urological literature. Journal of Urology 176, (5) (NOV): 1938-45.

Schagen, I., L. Kendall, and C. Sharp. 2002. Measuring the success of 'playing for success'. Educational Research 44, (3) (WIN): 255-67.

Schapira, M. M., S. L. Davids, T. L. McAuliffe, and A. B. Nattinger. 2004. Agreement between scales in the measurement of breast cancer risk perceptions. Risk Analysis 24, (3) (JUN): 665-73. 
$\mathrm{N}$

$\mathrm{N}$

N QL

$N$

$\mathrm{N}$

$\mathrm{N}$

$\mathrm{N}$

$\mathrm{N}$

$\mathrm{N}$
Scheaffer, R. L. 2002. Statistical bridges. Journal of the American Statistical Association 97, (457) (MAR): 1-7.

Schwartz, J. 1979. Does the UK have a numeracy problem. Nature 277, (5695): 344-5.

Schwartz, L. M., S. Woloshin, and H. G. Welch. 2005. Can patients interpret health information? An assessment of the medical data interpretation test. Medical Decision Making 25, (3) (JUN): 290-300.

Schwartz, L. M., S. Woloshin, and H. G. Welch. 2007. The drug facts box: Providing consumers with simple tabular data on drug benefit and harm. Medical Decision Making 27, (5) (SEP-OCT): 655-62.

Schwartz, L. M., S. Woloshin, W. C. Black, and H. G. Welch. 1997. The role of numeracy in understanding the benefit of screening mammography. Annals of Internal Medicine 127, (11) (DEC 1): 966-72.

Schwartz, S. R., J. McDowell, and B. Yueh. 2004. Numeracy and the shortcomings of utility assessment in head and neck cancer patients. Head and Neck-Journal for the Sciences and Specialties of the Head and Neck 26, (5) (MAY): 401-7.

Sharp, S. 2006. Assessing value-added in the first year of schooling: Some results and methodological considerations. School Effectiveness and School Improvement 17, (3) (SEP): 329-46.

Shepherd, P. 1984. Literacy and numeracy and their implications for survey-research - evidence from the national child-development study. Journal of the Market Research Society 26, (2): 147-58.

Sheridan, S. L., M. P. Pignone, and C. L. Lewis. 2003. A randomized comparison of patients' understanding of number needed to treat and other common risk reduction formats. Journal of General Internal Medicine 18, (11) (NOV): 884-92. 
Shield, B. M., and J. E. Dockrell. 2008. The effects of environmental and classroom noise on the academic attainments of primary school children. Journal of the Acoustical Society of America 123, (1) (JAN): 133-44.

Shorrocks-Taylor, D., J. Curry, B. Swinnerton, and N. Nelson. 2003. National curriculum mathematics tests in England at key stage 2: Weights and measures? Oxford Review of Education 29, (1) (MAR): 51-66.

Smerecnik, C. M. R., and I. Mesters. 2007. Validating the medical data interpretation test in a Dutch population. Patient Education and Counseling 68, (3) (NOV): 287-90.

Smith, F., F. Hardman, and S. Higgins. 2006. The impact of interactive whiteboards on teacher-pupil interaction in the national literacy and numeracy strategies. British Educational Research Journal 32, (3) (JUN): 443-57.

Smith, F., F. Hardman, and S. Higgins. 2007. Gender inequality in the primary classroom: Will interactive whiteboards help? Gender and Education 19, (4): 455-69. Smith, F., F. Hardman, K. Wall, and M. Mroz. 2004. Interactive whole class teaching in the national literacy and numeracy strategies. British Educational Research Journal 30, (3) (JUN): 395-411.

QL Smith, M. C. 1996. Differences in adults' reading practices and literacy proficiencies. Reading Research Quarterly 31, (2) (APR-JUN): 196-219.

Snyder, B. R. 1990. Literacy and numeracy - 2 ways of knowing. Daedalus 119, (2) (SPR): 233-56. statisticians to enhance their clients' numeracy. American Statistician 57, (2) (MAY): 89-93. Advanced Nursing 50, (6) (JUN): 633-40. 
$\mathrm{N}$

$\mathrm{N}$

$\mathrm{N}$

$\mathrm{N}$

$\mathrm{N}$

$\mathrm{N}$

$\mathrm{N}$

$\mathrm{N}$

$\mathrm{N}$

$\mathrm{N}$
Steele, J. M. 2005. Darrell Huff and fifty years of how to lie with statistics. Statistical Science 20, (3) (AUG): 205-9.

Steen, L. A. 1990. Numeracy. Daedalus 119, (2) (SPR): 211-31.

Steen, L. A. 1999. Numeracy - The new literacy for a datadrenched society. Educational Leadership 57, (2) (OCT): 8-13.

Stephens, T. T., C. L. Oriuwa, and M. Uzoho. 1999. Enhancing participation of women of child-bearing age in a literacy for health project in southeastern Nigeria. Tropical Doctor 29, (1) (JAN): 12-8.

QL SL Stroup, D. F., R. A. Goodman, R. Cordell, and R. Scheaffer. 2004. Teaching statistical principles using epidemiology: Measuring the health of populations. American Statistician 58, (1) (FEB): 77-84.

Sukon, K. S., and R. Jawahir. 2005. Influence of home-related factors in numeracy performance of fourth-grade children in Mauritius. International Journal of Educational Development 25, (5) (SEP): 547-56.

QL Sweet, S., and K. Strand. 2006. Cultivating quantitative literacy: The role of sociology - Introduction. Teaching Sociology 34, (1) (JAN): 1-4.

Tariq, V. N. 2002. A decline in numeracy skills among bioscience undergraduates. Journal of Biological Education 36, (2) (SPR): 76-83.

Temple, C. M., and P. Richardson. 2004. Developmental amnesia: A new pattern of dissociation with intact episodic memory. Neuropsychologia 42, (6): 764-81.

Thomas, K. 1987. Numeracy in early modern England. Transactions of the Royal Historical Society 37: 103-32.

Thompson, I. 2000. Teaching place value in the UK: Time for a reappraisal? Educational Review 52, (3) (NOV): 291-8. 
Torgerson, C. J., J. Porthouse, and G. Brooks. 2003. A systematic review and meta-analysis of randomised controlled trials evaluating interventions in adult literacy and numeracy. Journal of Research in Reading 26, (3) (OCT): 234-55.

Torgerson, C., J. Porthouse, and G. Brooks. 2005. A systematic review of controlled trials evaluating interventions in adult literacy and numeracy. Journal of Research in Reading 28, (2) (MAY): 87-107.

SL Trewin, D. 2005. Improving statistical literacy in schools in Australia. International Statistical Review 73, (2) (AUG): 211-2.

Turner, S., and A. Alborz. 2003. Academic attainments of children with Down's syndrome: A longitudinal study. British Journal of Educational Psychology 73, (DEC): 563-83.

Underwood, J., S. Cavendish, S. Dowling, K. Fogelman, and T. Lawson. 1996. Are integrated learning systems effective learning support tools? Computers \& Education 26, (1-3) (APR): 33-40.

$\mathrm{N}$

Upton, P., and C. Eiser. 2006. School experiences after treatment for a brain tumour. Child Care Health and Development 32, (1) (JAN): 8-17.

SL Utts, J. 2003. Special section on statistical literacy: How you can help. American Statistician 57, (2) (MAY): 73-.

SL Utts, J. 2003. What educated citizens should know about statistics and probability. American Statistician 57, (2) (MAY): 74-9.

Vakanas, G., Y. Laouris, M. Symeonidou, E. Loizou, S. Stylianou, P. Kouppe, and D. Georgiades. 1994. Mythology as a rich and meaningful context for integrated learning of literacy, numeracy and scientific inference - new possibilities. Exploring a New Partnership: Children, Teachers and Technology 58: 173-9. 
Van de Rijt, B. A. M., and J. E. H. Van Luit. 1999. Milestones in the development of infant numeracy. Scandinavian Journal of Psychology 40, (1) (MAR): 65-71.

Van de Rijt, B. A. M., J. E. H. Van Luit, and K. Hasemann. 2000. How to measure early numeracy. Zeitschrift Fur Entwicklungspsychologie Und Padagogische Psychologie 32, (1): 14-24.

van Kraayenoord, C. E., and J. Elkins. 2004. Learning difficulties in numeracy in Australia. Journal of Learning Disabilities 37, (1) (JAN-FEB): 32-41.

Van Luit, J. E. H., and E. A. M. Schopman. 2000. Improving early numeracy of young children with special educational needs. Remedial and Special Education 21, (1) (JAN-FEB): 2740 .

van Tol-Geerdink, J. J., P. F. M. Stalmeier, E. N. J. T. van Lin, E. C. Schimmel, H. Huizenga, W. A. J. van Daal, and J. W. Leer. 2006. Do prostate cancer patients want to choose their own radiation treatment? International Journal of Radiation Oncology Biology Physics 66, (4) (NOV 15): 1105-11.

van Tuijl, C., P. P. M. Leseman, and J. Rispens. 2001. Efficacy of an intensive home-based educational intervention programme for 4-to 6-year-old ethnic minority children in the Netherlands. International Journal of Behavioral Development 25, (2) (MAR): 148-59.

Vandewalle, E. 1992. Fertility transition, conscious choice, and numeracy. Demography 29, (4) (NOV): 487-502.

$\mathrm{N}$

Vavrus, F. 2006. Girls' schooling in Tanzania: The key to HIV. Aids Care-Psychological and Socio-Medical Aspects of Aids/hiv 18, (8) (NOV): 863-71.

$\mathrm{N}$

Vegas, E. 2007. Teacher labor markets in developing countries. Future of Children 17, (1) (SPR): 219-32. 
$\mathrm{N}$

$\mathrm{N}$

QL

$\mathrm{N}$

$\mathrm{N}$

$\mathrm{N}$

$\mathrm{N}$
Viswanathan, M. 1993. Measurement of individual differences in preference for numerical information. Journal of Applied Psychology 78, (5) (OCT): 741-52.

Viswanathan, M., J. A. Rosa, and J. E. Harris. 2005. Decision making and coping of functionally illiterate consumers and some implications for marketing management. Journal of Marketing 69, (1) (JAN): 15-31.

Vogel, S. A., and J. K. Holt. 2003. A comparative study of adults with and without self-reported learning disabilities in six English-speaking populations: What have we learned? Dyslexia 9, (4) (NOV): 193-228.

SL von Roten, F. C. 2006. Do we need a public understanding of statistics? Public Understanding of Science 15, (2) (APR): 2439.

Wade, B., and M. Moore. 1998. An early start with books: Literacy and mathematical evidence from a longitudinal study. Educational Review 50, (2) (JUN): 135-45.

Walker, S. 2005. Role of education and training in agricultural meteorology to reduce vulnerability to climate variability. Climatic Change 70, (1-2) (MAY): 311-8.

SL Wallman, K. K. 1993. Enhancing statistical literacy - enriching our society. Journal of the American Statistical Association 88, (421) (MAR): 1-8.

Waters, E. A., N. D. Weinstein, G. A. Colditz, and K. Emmons. 2006. Formats for improving risk communication in medical tradeoff decisions. Journal of Health Communication 11, (2) (MAR): 167-82.

Waters, E. A., N. D. Weinstein, G. A. Colditz, and K. M. Emmons. 2007. Aversion to side effects in preventive medical treatment decisions. British Journal of Health Psychology 12, (SEP): 383-401. 
SL Watson, J. M. 2002. Discussion: Statistical literacy before adulthood. International Statistical Review 70, (1) (APR): 2630.

SL Watson, J. M., and J. B. Moritz. 2000. Developing concepts of sampling. Journal for Research in Mathematics Education 31, (1) (JAN): 44-70.

Watters, D. J., and J. J. Watters. 2006. Student understanding of $\mathrm{pH}$ - "I don't know what the log actually is, I only know where the button is on my calculator". Biochemistry and Molecular Biology Education 34, (4) (JUL-AUG): 278-84.

Webb, N. 1984. Levels of adult numeracy. Journal of the Market Research Society 26, (2): 129-39.

Webb, R., and G. Vulliamy. 2007. Changing classroom practice at key stage 2: The impact of new labour's national strategies. Oxford Review of Education 33, (5) (NOV): 561-80.

Webber, L. S., J. C. Jenkinson, and J. A. McGillivray. 2002. Adaptive behaviour in Australia: What items are essential for assessing independent living? Australian Psychologist 37, (1) (MAR): 63-7.

Weinfurt, K. P., L. D. Castel, Y. Li, D. P. Sulmasy, A. M. Balshem, A. B. Benson, C. B. Burnett, et al. 2003. The correlation between patient characteristics and expectations of benefit from phase I clinical trials. Cancer 98, (1) (JUL 1): 16675 . Schulman, and N. J. Meropol. 2005. Understanding of an aggregate probability statement by patients who are offered participation in phase I clinical trials. Cancer 103, (1) (JAN 1): $140-7$.

SL Weldon, K. L. 2002. Adults' statistical literacy: Meanings, components, responsibilities - Discussion. International Statistical Review 70, (1) (APR): 43-4. 
Williams, M. V., R. M. Parker, D. W. Baker, N. S. Parikh, K. Pitkin, W. C. Coates, and J. R. Nurss. 1995. Inadequate functional health literacy among patients at 2 public hospitals. Jama-Journal of the American Medical Association 274, (21) (DEC 6): 1677-82.

QL Wills, J. B., and M. P. Atkinson. 2007. Table reading skills as quantitative literacy. Teaching Sociology 35, (3) (JUL): 255-63.

Wilson, L., C. Andrew, and J. Below. 2006. A comparison of teacher. British Educational Research Journal 32, (3) (JUN): 411-41.

Woloshin, S., L. M. Schwartz, M. Moncur, S. Gabriel, and A. N. A. Tosteson. 2001. Assessing values for health: Numeracy matters. Medical Decision Making 21, (5) (SEP-OCT): 382-90.

Wood, D., J. Underwood, and P. Avis. 1999. Integrated learning systems in the classroom. Computers \& Education 33, (2-3) (SEP-NOV): 91-108.

Wood, E. 2004. A new paradigm war? The impact of national curriculum policies on early childhood teachers' thinking and classroom practice. Teaching and Teacher Education 20, (4) (MAY): 361-74.

Wood, R., and J. Ashfield. 2008. The use of the interactive whiteboard for creative teaching and learning in literacy and mathematics: A case study. British Journal of Educational Technology 39, (1) (JAN): 84-96.

Yin, H. S., B. P. Dreyer, G. Foltin, L. van Schaick, and A. L. Mendelsohn. 2007. Association of low caregiver health literacy with reported use of nonstandardized dosing instruments and lack of knowledge of weight-based dosing. Ambulatory Pediatrics 7, (4) (JUL-AUG): 292-8.

Young-Loveridge, J. M. 2004. Effects on early numeracy of a program using number books and games. Early Childhood Research Quarterly 19, (1): 82-98. 
Zarcadoolas, C., A. Pleasant, and D. S. Greer. 2005.

Understanding health literacy: An expanded model. Health

Promotion International 20, (2) (JUN 1): 195-203.

Zikmund-Fisher, B. J., A. Fagerlin, K. Keeton, and P. A. Ubel. 2007. Does labeling prenatal screening test results as negative or positive affect a woman's responses? American Journal of Obstetrics and Gynecology 197, (5) (NOV): 528.e1.

N Zikmund-Fisher, B. J., D. M. Smith, P. A. Ubel, and A. Fagerlin. 2007. Validation of the subjective numeracy scale: Effects of low numeracy on comprehension of risk communications and utility elicitations. Medical Decision Making 27, (5) (SEP-OCT): 66 